\title{
Lung affection in individuals with rheumatoid arthritis
}

\author{
Almeida MSTM ${ }^{1}$, Almeida JVM² and Bertolo MB $^{3}$ \\ ${ }^{1}$ Maria do Socorro Teixeira Moreira Almeida, Universidade Federal do Piauí, Brasil

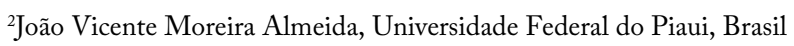 \\ ${ }^{3}$ Manoel Barros Bertolo, Universidade Estadual de Campinas, Brasil
}

\begin{abstract}
To establish the frequency of lung affection in individuals with rheumatoid arthritis (RA) from Piaui. Participants and methods: The sample comprised 97 individuals. Results: A total of 85 participants $(88.0 \%)$ were female; $77.0 \%$ were non-white; and the average age of the sample was 47.3 years old. A total of 54 participants (56.0\%) exhibited extra-articular manifestations, most frequently subcutaneous nodules (19.0\%). Lung assessment detected affection in 54 (55.7\%) participants.
\end{abstract}

\section{Introduction}

Rheumatoid arthritis (RA) is an autoimmune disease whose etiology is unknown, while its immunopathogenesis involves the participation of both genetic and environmental factors.

Although RA can affect any joint, the participation of the metacarpal, metatarsophalangeal, proximal interphalangeal, wrist and knee joints is most frequent and is characterized by swelling, sensitivity on palpation, morning stiffness and severe motion impairment [1].

Some patients also exhibit signs and symptoms of severe extraarticular affection involving distant organs [2]. The frequency of such manifestations is difficult to estimate, but they are known to occur more frequently among individuals with severe active disease [3].

The lung is a frequent site of extra-articular RA, reported to be either the second most common cause of death (18\%) following infection (27\%) [4-6] or the third (9.9\%) following infection $(23.5 \%)$ and cardiovascular disease (17.3\%) [3].

Pulmonary involvement in RA is highly variable; its earliest stage is usually asymptomatic, and the clinical manifestations are unspecific [7], usually including progressive dyspnea on exertion and dry cough [8].

The pathogenesis of RA as a systemic and lung disease has not yet been elucidated. [9]

The reported prevalence of lung affection among individuals with RA is variable. Such variability might be partially accounted for by the genetic basis of the investigated population as a function of the influence of genes, such as HLA-DR1 and HLA-DR4, on the phenotype of disease. Polymorphisms of the alleles HLA-B40 and B54 are particularly associated with lung abnormalities, fibrosis and bronchiolitis [10-11].

High-resolution computed tomography (HRCT) of the chest affords the best means for early diagnosis of lung disease in RA. Its diagnostic power was documented in a study in which it was able to detect interstitial lung disease in $50 \%$ of the participants with RA, whereas only $10 \%$ of them exhibited relevant clinical symptoms [12].

\section{Participants and methods}

\section{Participants}

The study was approved by the research ethics committee of the Federal University of Piaui; all the participants signed an informed consent form. The sample comprised 97 adult individuals from Piaui diagnosed with RA according to the American College of Rheumatology (ACR) revised criteria 12. The volunteers were followed up by the same physician at a university hospital and at the physician's private office and were requested to respond to a questionnaire including data on the age at onset, length of disease and the presence or absence of extraarticular manifestations.

\section{High-resolution computed tomography of the lungs}

The volunteers were subjected to HRCT, which was performed in a supine position, using a Siemens Somatom Spirit scanner with two channels and GE Healthcare LightSpeed Pro 16; all the scans were encoded.

\section{Pulmonary function test}

All participants were subjected to spirometry using a Beatrice Pulmonary Assessment System (Sistema de Avaliação Pulmonar Beatrice - PC). The device was coupled to a computer, and the results were compared to the predicted values for healthy individuals of the same age, gender and height (Brazilian Society of Pneumology and Phthisiology /Sociedade Brasileira de Pneumologia e Tisiologia SBPT) using the reference values used described by PEREIRA et al. [13].

\section{Results}

\section{Clinical characteristics}

Most participants were female (88.0\%) and non-white (77\%). The average age of the sample was 47.3 years old; the average length of

Correspondence to: Almeida MdSTM, Maria do Socorro Teixeira Moreira Almeida, Universidade Federal do Piauí, Brasil, E-mail: esteios@uol.com.br

Received: May 06, 2017; Accepted: May 25, 2017; Published: May 29, 2017 
disease was 7.72 years; and $84(87 \%)$ participants tested positive for RF. Extra-articular manifestations (subcutaneous nodules, anemia, skin ulcers, Raynaud's phenomenon) were identified in 54 participants (56\%), most frequently subcutaneous nodules (19\%); 32 volunteers (33.0\%) exhibited more than one type of extra-articular manifestation. Pulmonary symptoms were found in 35 participants $(36.0 \%)$, most frequently dyspnea (20.0\%), chest pain (13.0\%), dry cough $(11.0 \%)$ and productive cough (10.0\%) (Table.1)

\section{Lung involvement}

The pulmonary function test (PFT) results were normal in 65 participants $(67.0 \%)$, while $12(12.0 \%)$ exhibited restrictive ventilatory defect, 18 (19.0\%) obstructive ventilatory defect and $2(2.0 \%)$ a mixed pattern (Table.2).

On HRCT, the results were normal in 57 (59.0\%) participants, while nodules were found in $12(12.0 \%)$ and fibrosis in $31(32.0 \%)$ (Table.3). Joint analysis of the HRCT and PFT results indicated lung affection in $54(55.7 \%)$ participants.

\section{Discussion}

The clinical progression of RA is variable, including mild, moderate or destructive alterations, significant joint deformities, functional disability and extra-articular manifestations. The possibility of predicting the occurrence of extra-articular manifestations at the onset of disease might allow the establishment of more aggressive treatment at the early stages of affection [14]. HLA genotyping might contribute to defining the prognosis, especially when it is performed at

Table 1. RA - Disease characteristics of the 97 participants with rheumatoid arthritis

\begin{tabular}{|c|c|c|}
\hline F:M & & $85: 12$ \\
\hline White:non-white & & $23: 74$ \\
\hline Average age (years) & & $47.3 \pm 11.18$ \\
\hline Average length of disease (years) & & $7.72 \pm 7.79$ \\
\hline Positive rheumatoid factor & & $84(87 \%)$ \\
\hline Extra-articular manifestations & Total & $54(56 \%)$ \\
\hline & Nodules & $18(19 \%)$ \\
\hline & Anemia & $32(33 \%)$ \\
\hline & Ulcers & $05(5 \%)$ \\
\hline Pulmonary symptoms & Raynaud & $04(4 \%)$ \\
\hline & Weight loss & $20(21 \%)$ \\
\hline & Total & $35(36 \%)$ \\
\hline & Dyspnea & $19(20 \%)$ \\
\hline & Chest pain & $13(13 \%)$ \\
\hline & Cough & $21(21 \%)$ \\
\hline
\end{tabular}

Table 2. Results of pulmonary function tests in 97 individuals with rheumatoid arthritis

\begin{tabular}{|c|c|c|}
\hline Pattern & $\mathrm{n}(\%)$ & $\%$ \\
\hline Normal & $65(67 \%)$ & 67 \\
\hline Restrictive & $12(12 \%)$ & 12 \\
\hline Obstructive & $18(19 \%)$ & 19 \\
\hline Mixes & $02(2 \%)$ & 2 \\
\hline
\end{tabular}

Table 3. Findings on HRCT of the chest corresponding to 97 individuals with rheumatoid arthritis

\begin{tabular}{|c|c|c|}
\hline Pattern & N & $\%$ \\
\hline Normal & 57 & 59 \\
\hline Nodules & 12 & 12 \\
\hline Fibrosis & 31 & 32 \\
\hline Bronchiectasis & 05 & 5 \\
\hline Pleura affection & 05 & 5 \\
\hline
\end{tabular}

an early stage of the disease, i.e., before the establishment of irreversible joint damage and appearance of extra-articular manifestations [15]. As ethnic differences in gene determinants might influence the expression of the disease [16], we investigated the HLA system in individuals with RA from Piaui and compared the results for individuals with and without lung affection.

The results of this study show that most participants (54.6\%) exhibited some modality of lung affection. This high prevalence agrees with reports by previous authors, such as Skare et al. [18] who found lung alteration in $55 \%$ of 71 individuals; Zrour et al. [17], who found lung alteration in $49.3 \%$ of 75 individuals in Tunisia; and Bilgici et al. 6 who found lung alteration in $67.3 \%$ of 52 individuals in Turkey. In addition, Teraski et al. [19] assessed a sample of individuals with RA and respiratory symptoms and found CT changes in $90 \%$ of them.

\section{Conclusion}

In this study, 54.6\% exhibited some modality of lung affection.

\section{References}

1. Grassi W, De Angelis R, Lamanna G, Cervini C (1998) The clinical features of rheumatoid arthritis. Eur J Radiol 27 Suppl 1: S18-24. [Crossref]

2. Turesson C, Jacobsson L, Bergström U, Truedsson L, Sturfelt G (2000) Predictors of extra-articular manifestations in rheumatoid arthritis. Scand J Rheumatol 29: 358-364. [Crossref]

3. Turesson C, Jacobsson L, Bergström U (1999) Extra-articular rheumatoid arthritis: prevalence and mortality. Rheumatology 38: 668-674. [Crossref]

4. Tyoshima H, Kusaba T, Yamaguchi T (1993) Cause of death in autopsied rheumatoid arthritis patients. Ryumachi 33: 209-14.

5. Anaya JM, Diethelm L, Ortiz LA, Gutierrez M, Citera G, et al. (1995) Pulmonary involvement in Rheumatoid Arthritis. Semin Arthritis Rheum 24: 242-254. [Crossref]

6. Bilgici A1, Ulusoy H, Kuru O, Celenk C, Unsal M, et al. (2005) Pulmonary involvement in rheumatoid arthritis. Rheumatol Int 25: 429-435. [Crossref]

7. Prete M, Racanelli V, Digiglio L, Vacca A, Dammarco F, et al. (2011) Extra-articular manifestations of rheumatoid arthritis: An update. Autoimmunity Reviews 11: 123.131. [Crossref]

8. Nannini C1, Ryu JH, Matteson EL (2008) Lung disease in rheumatoid arthritis. Curr Opin Rheumatol 20: 340-346. [Crossref]

9. Migita K, Nakamura T, Koga T, Eguchi K (2010) HLA-DRB1 alleles and rheumatoid arthritis-related pulmonary fibrosis. J Rheumatol 37: 205-207. [Crossref]

10. Charles PJ1, Sweatman MC, Markwick JR, Maini RN (1991) HLA-B40: a marker for susceptibility to lung disease in rheumatoid arthritis. Dis Markers 9: 97-101. [Crossref]

11. Sugiyama Y, Ohno S, Kano S (1994) Diffuse panbronchiolitis and rheumatoid arthritis: a possible correlation with HLA-B54. Inter Med 33: 612-4.

12. Lioté H1 (2008) [Pulmonary manifestation of rheumatoid arthritis]. Rev Mal Respir 25: 973-988. [Crossref]

13. Pereira CAC, Carvalho CRR, Nakatani J (1996) Pneumologia - Atualização e Reciclagem [Pneumology - updates and continuing education] - Sociedade Paulista de Pneumologia e Tisiologia, Ed. Atheneu.

14. Emery P1, Salmon M (1995) Early rheumatoid arthritis: time to aim for remission? Ann Rheum Dis 54: 944-947. [Crossref]

15. Gough A, Faint J, Salmon M, et al. (1994) Genetic typing of patients with inflammatory arthritis at presentation can be used to predict outcome. Arthritis Rheum 37: 1166-1170. [Crossref]

16. Bertolo MB, Costallat LTL, Persoli LB, Costa FF. Alelos HLA-DRB1 (2001) e o prognóstico da artrite reumatoide em pacientes brasileiros [HLA-DRB1 alleles and prognosis of rheumatoid arthritis in Brazilian patients]. Rev Bras Reumatol 41: 151156

17. Zrour SH, Touzi M, Beijia I, Golli M, Rouatbi N et al. (2005) Correlations between high-resolution computed tomography of the chest and clinical function in patients with rheumatoid arthritis. Prospective study in 75 patients. Joint Bone Spine 72: 41-7. [Crossref] 
18. Skare TL, Nakano I, Escuissiato DL, Batistetti R, Rodrigues TO, et al. (2011) Pulmonary changes on high-resolution computed tomography of patients with rheumatoid arthritis and their association with clinical, demographic, serological and therapeutic variables. Rev Bras Reumatol 51 (4): 325-337. [Crossref]
19. Teraski H, Fujimoto K, Hayabuchi N, Ogoh Y, Fukuda T (2004) Respiratory symptoms in rheumatoid arthritis: relation between high resolution CT findings and functional impairment. Radiat Med 22: 179-85. [Crossref]

Copyright: ( 02017 Almeida MS. This is an open-access article distributed under the terms of the Creative Commons Attribution License, which permits unrestricted use, distribution, and reproduction in any medium, provided the original author and source are credited. 